\title{
Between immediacy and imagination: the place of the educator and organiser in union renewal ${ }^{1}$
}

TONY BROWN

University of Technology, Australia (Tony.brown@uts.edu.au)

KEIKO YASUKAWA

University of Technology, Australia

\begin{abstract}
Can the current education programme of the Australian trade union movement contribute to reviving union growth and union culture, develop new activists and leaders, and encourage and facilitate the organisational change needed to re-orient unions to develop broader alliances? Twenty-five Australian trade union leaders were asked to describe the educational activities of their unions and to assess the education provided by the Australian Council of 'Trade Unions' (ACTU) national Education and Campaign Centre (ECC). Analysis of their responses reveals a number of structural, organisational and pedagogical challenges for delivering a national union education programme. It also raises questions of how education can support a union movement trying to convince new layers of workers that unionism can be a dynamic, forward-looking, social movement. The article outlines the existing course framework as a means of understanding the scope of current educational provision. Drawing on interviewee observations and Newman's concept of three contracts in union education, it considers the roles of educator and of organiser, and how an understanding of these roles is currently expressed by union leaders. We conclude with some questions about ways that the union movement might consider the relationship between education and union renewal.
\end{abstract}

\section{Keywords}

union education; critical education; union renewal

\section{Introduction}

Australian trade union education has undergone a series of reorganisations since the election of the Conservative Coalition Government in 1996. One of the 
Coalition's first acts was to abolish the government-funded Trade Union Training Authority (TUTA). Since then, the national education arm of the ACTU (Australian Council of Trade Unions) has been restructured four times. Throughout this period, unionism has been under constant legislative attack and membership density has continued the decline that commenced in the mid-1980s, with membership falling from 55 per cent of workers in 1982 to 19 per cent in 2007.

A recurring tension for trade unions in the past quarter century, and especially during the past decade, has involved dealing with the short-term and long-term issues. Trade unions need to respond to the immediate pressures in the short-term as well as prepare for the long-term by developing strategies, policies and people to imagine a different future and a means of getting there consistent with the ideals of that future.

Because falling membership and density levels have been so dramatic, many unions have re-focused their energies on recruiting new members by adopting new organising methods aimed at first halting and then turning around the sharp decline. Some saw experienced organisers as the most effective means of passing on their knowledge and skills to newly recruited organisers. However this highlighted another tension between the roles that organisers and educators play in a time of renewal and change, between the need to transfer practical organising skills and, at the same time, to educate the development of critical analytical thinking. We argue in this paper that negotiating these tensions requires union leaders and organisers to re-think their practices and priorities, and suggest that the kind of education that is needed requires union educators who have skills and knowledge of educating adults that are not the same as, nor replaceable by, the skills and knowledge of organising and leading campaigns. For this reason, the paper focuses on the union leaders' views about the ACTU's national Education and Campaign Centre's (ECC) approaches to education and training and specifically about the roles of the organiser and educator.

The article commences by outlining the existing framework of courses as a means of understanding the scope and ambitions of the unions' current educational outlook. Secondly, it presents a framework for analysing the potential of union education to effect change. Newman (1993) argues that there are three contracts that shape union training programmes: the first between unions and educators/trainers; the second between the educators/trainers and programme participants; the third between programme participants and their union. The three contracts will be used as a point of reference for examining the ECC programmes. In addition, Horton's (1998) discussion on the special role of educators in union and movement learning along with Wheelahan's $(2007,2008)$ use of Bernstein's concept of vertical and horizontal knowledges, will be drawn on in the analysis. The third section analyses the data from the research against these educational frameworks and examines whether, in the context of declining membership and thinning membership density, the current understanding of union education and the role of union educators, held by Australian union leaders, is likely to contribute to reviving union growth and a culture for imagining a different future. In the final section we argue that a re-examination and clarification of the aims and orientation of union education, and the place and role of the union educator, are needed in order for the movement to meet the challenge of renewal. 


\section{Research background}

During late 2007 and early 2008, twenty-five Australian trade union leaders were interviewed about the education and training programmes conducted by the ECC, the third reincarnation of the ACTU's education and training arm. ${ }^{2}$ The research involved semi-structured interviews with presidents, secretaries and senior officials of state and national unions who were asked to describe the educational activities of their own unions and to assess the education provided by the ECC. We found that factors including the size of the union, their history of education and training provision, resource constraints, their perception of their own uniqueness and distinctiveness, and their organisational strategies influenced how they organised and prioritised education and training in their union. Systematic planning and follow-up of training were not strong features for many of the unions. While the majority of the leaders considered their own union as low users of the ECC, there were several that had a strong sense of trust and allegiance to it and had developed a close partnership with the planning, design and delivery of ECC programmes.

Union leaders' concerns were focused largely on the immediate returns and limitations of the education programmes, and there was little consensus either about the value of what the ECC was currently doing, or what a national union education programme should look like in the future despite general support for the idea of a national centre (Brown and Yasukawa, 2009). The interviews also revealed that many leaders' views were based on perceptions about the ECC that were not always informed by recent or direct engagement with it. Moreover, the level and nature of communication between the ECC and the union leaders was very uneven. Despite the lack of recent first-hand experience and contact that many of the leaders had with the ECC, all held views - many of them conflicting about the quality of the centre's programmes, the content and methods of courses, and what a national education programme should look like.

The interviews were conducted in the period prior to and following the 2007 elections that lead to the defeat of the Howard government. Over the two years leading up to the election, the union movement had built a highly disciplined and successful YourRights@Work, community-based campaign, with the aim of defeating the anti-union WorkChoices legislation of the government. Unions had an immediate agenda that they organised around, however, critical reflection on the campaign suggests that the movement had not sufficiently planned for the post-YourRights@Work context. What should come after the campaign was won beyond repealing an unpopular piece of legislation - and how the momentum achieved could be built upon had been given inșufficient attention (Ellem, 2009; Muir, 2008). The need to address the level of critical learning within the union movement is suggested by these studies of the YourRights@Work campaign; and a similar observation emerges from this research about the place and role of organisers and educators in union renewal efforts.

\section{Union education and training programmes of Australia's national education and campaign centre}

Like unions across the industrialised world, and especially in English-speaking countries, Australia's unions experienced a serious decline in membership and density levels through the 1980 s and 1990s. Density fell by nearly two-thirds 
from 55 per cent to 19 per cent between 1982 and 2007, before registering a small increase to 21 per cent in 2008 (ABS 2008; Brown 2006, 2007). These trends pose new questions for unions about how to respond to external factors, but they also require unions to consider a set of questions about internal capacity. Are unions capable and equipped to make the changes necessary to redefine their purpose, structures and profile?

It was in this context that union leaders called for new revival strategies to grow union membership by recruiting in new areas of the economy and among previously unorganised sectors, as well as targeting young, female and immigrant workers who had not previously been approached to join unions. Recognising that union strength has to be re-established at the base, the ACTU adopted an 'organising model' with its policy document Unions@work (ACTU, 1999), which was refined in Future Strategies (ACTU, 2003).

Organisers as lynchpins between leadership and membership are identified as pivotal for implementing change. Their roles are also extended to include being 'educators, with the delivery of union education no longer just the role of dedicated trainers' (Labour Council NSW, 2003). A greater emphasis is placed on new organising and education methods, as well as on forging community alliances and developing new political tactics. Arguably the new organising practices require both labour educators and organisers to see their roles, and therefore their practices, in different and broader terms (Fletcher, 1998; Crosby, 2002).

The abolition of TUTA by the Howard government was accompanied by cuts in funding for various programmes that had enabled unions to employ education and training staff. With union membership continuing to fall, income also declined and staff employed as trainers were not replaced and a number of unions, especially smaller and state-based unions, decided to close their education units in favour of retaining other specialist functions such as a legal officer or health and safety sections. While some larger unions retained their education departments many became increasingly reliant on the national centre, consultants and external providers; alternatively they have cut back on training for members, activists and staff altogether. Not only did the capacity of unions to provide internal education and training decline, but their involvement in shaping public policies on education also diminished during this period. This could be attributed to the reduced capacity of unions generally. Backed strongly by employer groups who occupied the spaces previously filled by unions, however, the government maintained a commitment to neo-liberalism as a basis for public policy development and refused to involve unions in policy consultation or on government-sponsored committees.

Under the Howard government's WorkChoices regime, it became much more difficult for members to get release time from work and delegates to undertake trade union training. This required a shift in practice to deal with these changes. At the time of the interviews, unions were on the back burner, merely reacting to employers' and government agendas and in some cases were in basic survival mode. This is one possible explanation for why many ECC courses were being cancelled due to low uptake, with education seen as a long-term investment that was a luxury in the years leading up to the 2007 election. An alternative view is that this is precisely the time when education is needed - to plan for the longer term and create a vision that can sustain and expand the community activism that clearly helped the YourRights@Work campaign. 


\section{Approaches to analysing union education programmes}

Educational programmes for organisers and union staff can be analysed along a number of different lines to understand how education and training can make a productive intervention for effecting change. These include, firstly, the models that are used to plan and design programmes, secondly, the knowledge domains and pedagogical orientations of the programmes, thirdly, the role and status that are ascribed to union educators and trainers and, fourthly, the political contexts in which the preceding three aspects are negotiated.

In developing a union education programme, the planning and design are informed by questions relating to the purpose and context of the programme, the skills and knowledge content to be addressed, the needs that are to be met, pedagogical approaches and lastly forms of assessment. Programme planners are invariably influenced by their working beliefs about education and learning, and those with a critical orientation might further interrogate those questions informing the design of the programme to include as follows:

- Whose purpose is the programme serving?

- What is the political, economic, cultural context in which this programme is taking place?

- Who decides what and whose needs have to be met and how are the training and education activities related to organisers' professional development?

- Whose knowledge and experience will be privileged in the learning and what knowledge is valued?

- What is the purpose of assessment?

The extent to which these latter questions are explored influences both the knowledge domains that are addressed, and the pedagogical orientations that are taken in the programmes.

Australian union education has traditionally focused on tools, techniques and issues-based courses, supplemented by courses on social and political themes, at times drawing on adult education methods and in the best cases stimulating critical thinking and questioning. Recent education programmes have emphasised three aspects of the new approach focusing on:

1. instrumental techniques - these range from very traditional courses on being a workplace representative, understanding occupational health and safety, and other legislative or industrial instruments through to courses associated with the craft of organising that seek to achieve what might be described as operational, skills-based or practical learning;

2. communicative techniques - these advocate attention to listening and communication skills; identification of issues nominated by members and potential members; establishing contacts with non-unionists and community groups, and focus on what might be described as the expressive, affective, humanistic or interpersonal dimensions of organising; and

3. critical understanding - these interrogate the changed political, economic, employment and legal environment; the reasons why unions need to change; the need to develop new activists, devise and understand new strategies for labour to influence economic change and community development, and connect 
these by being able to articulate a vision of a different, more democratic, respectful and egalitarian future; they focus on what might be described as the purpose and wider vision of unionism.

This third type, of course, is the least developed and highlights the challenge involved in translating the theory of organising into practice. It is also the activity most often provided for existing leaders but not generally available to activists and delegates. Learning the 'how' of organising is not so difficult, but more important and more challenging, is to know the 'why', for it is understanding the why that enables individuals to be able to adapt tactics, to know when to advance or to hold their ground, to apply these lessons to future activities that may be similar but where they may be operating in a different context. These are higher order analytical skills that ideally can be used in different circumstances.

Consistent with the above Habermasian framework for understanding knowledge domains and education is Illeris' (2002) idea of a 'tension field' of learning (see also Sawchuk's 2006 adaptation). Illeris represents the tension field as a triangle. At one vertex (cognitive) is the need to know how to do things, to develop skills and act upon the world; at another (interpretive) is the need to be able to communicate with others, to listen and speak, to establish dialogue and to create a shared meaning; at the third (critical) is the need to question, to exercise choice, to think and act collectively and to exercise the agency needed to make change.

The above knowledge domains, and the pedagogical orientations that underpin the approach in the programmes, will influence or be influenced by the role assumed by the union educator and the skills and knowledge base they bring to it. If the focus of the programme is for the participants to acquire a set of skills, say in organising, then what might be expected of the trainer is expertise and experience in organising that the course participants can learn from. Or, they might seek a trainer who has, in addition to being the 'expert' in organising, the skills to engage participants in sharing their own experiences of organising among themselves in order to devise ways of using these insights to effect change.

Drawing on his early experience gained through the Wilder Coal strike, and later working with the new industrial unions affiliated with the American Congress of Industrial Unions, and then with the Citizenship Schools and civil rights organising, Myles Horton (1998) discussed the role of movement educators in relation to the different stages of organisational and movement development. For Horton, the purpose of the Highlander School was to 'multiply leadership for social change' (Horton, 1998, p. 115) and the means of achieving that end was to avoid telling people what they needed to know and instead find ways to 'use situations to educate them so that they can learn to figure things out themselves' (Horton, 1998, p. 122). He believed that the knowledge needed for the solution to a problem had to be created in concert with others who also were looking for a solution. For Horton, people's experience was the curriculum, and the analysis of that experience was the focus for learning. The educational purpose is to take learning back to communities to effect change, and the role of the educator is to 'develop people's ability to analyse, to understand problems so that they can develop into organisers or other types of leaders' (Horton, 1998, p. 148). In helping people analyse, he also wanted to get them 'committed philosophically to working for a more humane and just society' (Horton, 1998, p. 176). 
Horton concluded that there were distinctive roles played by educators and organisers in union education while also acknowledging the temptations involved in abandoning the educator's role in favour of the more charismatic one of organiser and leader. His argument remains relevant for organisations and movements that are interested in helping people to develop analytical skills, in creating opportunities to learn rather than concentrating on didactic teaching or simply affirming learners' experiences, but not learning from them. The educational role is quite different from the role the organiser plays and requires different skills and approaches as well as a different understanding of the nature of the work involved. A question then arises about what kind of knowledge union educators need in order to develop analytical skills among union course participants.

Wheelahan $(2007,2008)$ draws on Bernstein's analysis of vertical (abstract, conceptual) knowledge and horizontal (everyday, mundane) knowledge to characterise the kinds of knowledge that vocational education courses ought to address, and this analysis can also be applied to union training and education. Should the trainer just bring a wealth of the 'mundane and everyday' knowledge of organising, perhaps drawing out this knowledge from participants? Or should the trainer also aim to facilitate learning the kinds of knowledge that will enable the participants to work with their experiences, but also involve stepping back and critically reflecting on this experience in order to create new understanding and knowledge about organising, unionism and social change?

Newman's work (1993) draws attention to three contracts operating in trade union training. The nature and strengths of these contracts influence the design of the programme, what knowledge domains are addressed, the role and the expertise of the union educator, and the pedagogical approach adopted.

One contract is between the union and the trainer. The trainer, whether they are internal to the union, or engaged from a training provider, enters a contractual relationship with the union to train the participants who may be union staff, delegates or activists. The negotiation of this contract involves coming to some understanding about the course design, course objectives, administrative processes, overall programme objectives and union policy.

The second contract is between the trainer and the participants of the programme. Here there are also programme elements that are subject to negotiation. These include the course objectives, course design, session objectives, session design, and choice of methods.

The third contract is between the union and the participants. This contract includes: policy and proposals, evaluation, feedback, testing, and learning; that is, the participants bring back the learning from the course to their work or their union workplace and test what they have learned. The transfer of learning may or may not be formally assessed by the union's officers, but this is where the programme's effectiveness and relevance is put to the test (Newman, 1993, pp. 38-39).

The nature of these three contracts, and how they are negotiated, can reveal assumptions that the different stakeholders have about what should happen in an education programme and the real purpose of the training. Newman (1993, p. 267) concludes from his assessment of the literature that there are two broad ideological orientations: radicalism and labourism, which have characterised trade unions in Australia. Radicalism, he explains, sits to the left of the . 
political spectrum and involves the belief that the union movement should be a revolutionary movement that seeks to replace capitalism with a more socialistoriented social system. Labourism, on the other hand, is a reformist orientation that accepts more gradual, pragmatic approaches based on the belief that positive change can emerge from the traditional political and industrial negotiation processes and systems.

According to Newman (1993), the first contract between the union and the trainer is typically based on a labourist orientation. He explains, however, that in some situations, opportunities of movement from a labourist to a radical orientation can emerge within the training programme, that is, as part of the second contract. This would particularly be the case if the educational process promotes programme participants to think critically, recognising for themselves the issues that can change and develop as a plan for action emerges. Such a situation contrasts with a training programme where the trainer is training the participants to merely develop skills and knowledge that would strengthen the status quo or what the trainer believes to be important. It also contrasts with a training situation where participants are encouraged to share their experiences without any critical analysis and considerations of new possibilities. If such a shift occurs among participants in the training context, about their own approaches and understanding of the union's direction, it is in the negotiation of the third contract between the participants and their union (as an organisation) that the learning can lead to change in the union's policy.

There is, however, another dimension to the contract between the trainer and the participants implicit in Newman's model. This is the aspect of the trainer's role and what it means. In union education, it would be usual that a trainer of an organisers' course would have experience in the union movement. In some cases, they would have extensive experience not only in the movement but more specifically as organisers. However, there is a question about whether there is a role distinction to be made between an organiser and an educator. Is the prime concern to have an expert organiser or an adult educator? Is the participants' contract with an organiser or educator? With whom has the union formed a contract in sending their organisers to an education programme?

The three contracts describe some of the political dimensions of union education programmes that in turn influence the design of the programme, its content and approach, the role and expected expertise of the educator and the extent to which the union can change through the learning that the programme participants experience. Examining the nature of these three contracts operating in union education programmes can reveal what kinds of educational possibilities emerge for the movement.

\section{What do union leaders think about the ECC courses and services?}

All of the union leaders that were interviewed, whether their union was a user or non-user of the ECC, held strong views about the approaches and relevance of its courses. Some of the views were from leaders who were informed by first-hand information and experience, while others were strongly held perceptions that were not clearly linked to the ECC's current activities. Those unions that not only used ECC courses, but worked with ECC staff to shape the courses to meet the 
needs of their union reported satisfaction with the outcomes. However, there were many unions that were working on the basis that ECC course structures, content and approaches were non-negotiable and fixed.

In terms of Newman's framework, the 'strength and nature of the contract between the union and the ECC are variable throughout the movement, even in cases where the unions are users of the ECC. For some, the contract involved codesigning new curriculum or customising ECC courses to meet the union's specific priorities. One national secretary said:

I have relationships with people there... [So we use the ECC for] something that we can't or wouldn't do ourselves ... we think it might be a better experience or because we simply don't have the capacity to do it internally at a point in time (NS11).

For others, the contract was based on an unquestioned allegiance: 'It's run by the ACTU, ... that's where our money would go' (SS1), while for others a significant factor that formed the basis of the contract was economic:

We previously did our own internal training and had our own training calendar, but we found that the size of our branch, because we're a branch of a national union, we just don't bave the internal capacity so it wasn't sometbing that we can sustain (SS25).

Some felt they were able to benefit from the ECC through working collaboratively with them, while others felt 'a real lack of connection between the training the ECC] provide and what the unions are actually doing' (SS14). In this case and for another low-level user (NS8), the respondents mentioned a loss of trust in the relationship between their union and the ECC.

Another low-level user (SS16) expanded on the nature of the lack of connection between the ECC's focus and their union's needs.

The focus [of the ECC training]... was about everytbing being about growth and I understand that, but if you then go back to a clothing worker wbo's working in a clotbing factory that has seen 2,000 jobs lost over the last couple of years and you put that delegate into that environment you can see why there's a problem (SS16).

This union believed the ECC had to give greater acknowledgement to the harsh working environment and massive job losses, and offer training that is appropriate for delegates working in those environments. This means that keeping any industrial presence is itself a formidable challenge.

For another union, the ECC was not sufficiently responsive to changes in white-collar work. 'There has been this revolution in working practice on whitecollar employment in business and management thinking which we're actually not really engaging staff in' (NS24). The secretary explained that he was referring to the increasingly contingent nature of employment in the white-collar sector where his union is based, but 'whenever anyone talks about organising, they always talk in the context of here's a workplace with a couple of hundred continuing employees working there'.

Some of the disconnection was simply a lack of communication and awareness of what the ECC did. One assistant state secretary would like to see the ECC be "just a little bit more aggressive in maybe sending us a monthly newsletter... that lets us know what they're doing' (SAS7) whilst a national union secretary said, 'I don't even know what they do in the courses anymore or what courses are really on offer' (NS22). 
It is not surprising that those union leaders, whose contract with the ECC is based on something other than joint programme planning with it, are influenced by the variable responses from the delegates or staff that they send to their courses. One of the areas that several union leaders held concerns about was the disjuncture that their staff felt with the course content because the union saw themselves as having unique needs, arising from the characteristics of their staff and delegates or their industry sector, and these were not sufficiently considered in 'generic', multi-union, training courses. One blue-collar union leader (NO2) said:

I think there's a problem with theory - a lot of the courses are very theoretically based, a lot of the case studies are very white-collar based, they baven't actually got experience within their unit to be able to articulate it in a blue-collar environment (NO2).

Alternatively, there were white-collar union leaders who perceived ECC courses as being mainly suited for blue-collar unions: 'There's no dialogue about trying to get some sort of examples around [the content] because it's very blue-collar, private sector dominated rather than looking at some of the variations' (NS13). For a few unions, ECC courses were 'formulaic and ... you can't question it ... other approaches to organising are not encouraged or ... there isn't enough recognition of differences between unions' (SS10). In some cases, the formula is seen in terms of 'delivering the doctrine' rather than looking at the practical issues of having to settle deals at some point. One state secretary felt the ECC approach encourages participants to always be looking to 'be in dispute, you always have to agitate, ... you end up getting people who get burnt out because they can never see a way to closing the circle of a dispute - be it staff or members' (SS1).

These comments about the courses and the approaches employed by the educators raise questions about how the ECC and the union leaders, their staff and delegates think about the kinds of learning that a union course should be about and the role of the union educator. The nature of the first contract between the unions and the ECC could leave these questions unresolved, or perhaps even unrecognised, until tensions and conflicts emerge at the site of training. Because of the weakness of the first contract, the second contract is also left ambiguous.

The function of the courses, and the kind of learning that is likely, also influence what is expected of the union educator and their approach. At the level of pedagogy, some interviewees had very strong views about what type of approach was and was not appropriate. While some unions stated that the ECC courses use a mix of effective teaching methods that are hands on - such as role plays, some found role-plays 'absolutely useless in most cases' (SP4), while others found the interactive approaches 'a totally different thing - more dialogic and involving participants' (NPG) and preferable to lecture methods. Another representative also said that interactive approaches do not suit some of their members and staff because in their industry members 'like to cut to the chase' (SO5).

Many commented on the value of training that drew on examples that the participants could identify with. The recurring comments about courses having relevance to the particular industry sector in which the participants worked may be interpreted as an expression of a need for immediately practical outcomes and a primarily instrumental focus that unions have for training. 
Most union representatives commented on the quality of trainers in terms of their level of experience in the union movement as organisers and their knowledge and experience of the industry of their union. One state secretary lamented:

There used to be people that were ... very experienced trade unionists that would be running the courses, and you really want your people to go.... Now the people it seems [have] a couple of years maybe as an organiser and they're meant to be training people, many who have more experience than them. And I don't have any faith in that (SS14).

The quality of the current group of trainers was questioned in a different way by a national secretary (NS22): 'The old guard who have been around since the 1990s were very experienced educators... but probably didn't have a lot of organising experience', while the 'new guard had some limited organising experience' and generally did not have a strong educational theory background and were 'not very deep' in their approach.

Thus, among one significant group of stakeholders - the union leaders - there is not a consensus of what the role of a union educator should be. Are they union activists with a greater level of experience than the people who come to the courses, and whose role is to share their expertise in union organising? Or are they educators who can draw out the experiences that course participants bring and use their pedagogical skills to help participants critically examine their own and others' experiences in order to generate new understandings, to be able to work in changing contexts, innovate, and influence others?

The union educator as experienced organiser assumes that the knowledge and skills that are important are those of union organising. Whether those knowledge and skills are learnt by the participants through a didactic approach, or through dialogue, the foregrounding of the organising expertise suggests that the purpose of education is more about learning the 'right' skills, rather than questioning and critically analysing why the skills they are learning can lead them to be part of the growth and strengthening of their union.

The lack of attention by the union leaders to the kinds of education that were, or should be taking place in training, was consistent with the lack of follow-up after the training. Many of the union leaders explained this was a resourcing problem. Thus the third strand of the contract, between the course participants and their unions, was not strongly established. Had the course participants gained critical insights about what changes in their union's current practices might be desirable, the likelihood of their ideas being heard and supported as part of the union's learning as an organisation would be slim. This begs the question - what is the education and training for if not a strategic investment by the union to educate the delegates and organisers to develop their capacity to think critically and analytically about ways of strengthening and growing their union?

\section{Conclusion}

The picture that emerges of the state of the national education centre's programmes is that it is fragmented because of the fragility of the contracts between the three major stakeholders: the union, the education centre, and the course participants. There is a lack of general acknowledgement that the centre can play a role in educating activists to critically engage with the project of achieving social change. Much of the emphasis is instrumental, based on an assumption that people go to 
courses to acquire skills from experts. This then positions the union educators as trainers who need to be experts in the skills that they impart to participants.

Contracts between the stakeholders that are based on a different set of assumptions about the purpose of educational programmes run by the national centre could position the union educator differently, and require a different kind of skill and knowledge that can lead to different kinds of outcomes for those who participate in the courses. If the purpose of the programme is to educate the participants for critical understanding of their own and the wider labour context, it may be less important that the union educators are equipped with experience of organising because more important are the skills to facilitate analysis, critique and questioning of the participants' own experiences. Such an education would involve participants in learning 'horizontal and vertical knowledges', so they have the language and the concepts to undertake the analysis and critique to generate new knowledge. For the educator, facilitating this kind of learning requires engagement with the vertical discourses of the educator, that is, to have access to the language and knowledge that help them to design and create learning opportunities and environments that support the critical dimensions of learning.

Education often does not deliver an immediate solution to an immediate problem. Its best outcome is to bring together the ability to think and the ability to act, that is, to be critically conscious. This requires a commitment to a longer-term analysis and one that requires critical dialogue because it is through this that a bridge between the long-term and the present, that requires a more 'immediate' response, can be made. Creating the environment for such critical dialogue is a vital need and all the more important for a movement looking to engage with 'external' social movement and community organisations with different starting points, cultures and agendas. It is an environment that a national education centre could stimulate.

This points to a bigger question of recruitment, retention, and opportunities for placement, exchange and ongoing professional development of education staff, as well as a broader issue of career pathways within the labour movement more generally. It also poses a question as to whether the perception of the educator can be shifted so that it is seen as one that attracts and retains experienced unionists and/ or educators. In addition to examining recruitment policies it may also mean that policies to support adult teaching and learning development should be examined.

Expecting delegates and union officers to work effectively in the challenging industrial, social and political environment of the early $21^{\text {st }}$ century, without a contemporary education programme to educate, support and develop them is shortsighted. Unions already commit significant resources to the education of their members, delegates and staff, but whether this commitment is achieving the intended objectives or reaping the anticipated benefits is less clear.

Addressing the purpose, quality and quantity of union education and learning is important, as is committing the resources needed to deliver the expectations which require intellectual, political and financial commitment.

\section{Notes}

1 Research for this paper was presented at the $23^{\text {rd }}$ AIRAANZ Conference, Labor, Capital \& Change in Newcastle Australia, 4-6 February 2009; and the United 
Association for Labor Educators (UALE) Conference Imagining Alternatives: the challenge to labor, at the National Labor College, Maryland, 16-18 April 2009.

2 The Organising Centre was the first post-TUTA centre established in 2001, and renamed the Education and Campaign Centre in 2005. In 2008 it was re-organised as the Organising, Education and Campaign Centre.

3 When reporting interviewees' comments we have used a code - NP; NS; NO refers to a national president, secretary, or officer and the number refers to their interview number. Similarly SP, SS, SAS, SO refers to a state president, secretary, assistant secretary or officer and their interview number.

\section{References}

Australian Bureau of Statistics (2008). Employee Earnings, Benefits and Trade Union Membership, Australia, Cat No. 6310.0. Canberra, Australian Government Publishing Service AGPS.

Australian Council of Trade Unions (1999). Unions@work: The Challenge for Unions in Creating a Just and Fair Society. Melbourne, ACTU.

Australian Council of Trade Unions (2003). Future Strategies: Unions Working for a Fairer Atustralia, Melbourne: ACTU. Retrieved 9 April 2009, from http://www.actu.asn.au/Archive/ ACTUCongress/Congress2003/DraftPolicy/FutureStrategiesPart2UnionsAndTheWorkplacePolicy.aspx

Brown, T (2006). 'Organising for the future: Labour's renewal strategies, popular education and radical history', Studies in Continuing Education vol 28 no 1, pp 33-48.

Brown, $T$ (2007). 'Organisational Learning: How Organising Changes Education in Trade Unions', Economics and Labour Relations Review, vol 17 no 2, pp 165-181.

Brown, $T$ and Yasukawa, $K$ (2009). 'Education at the centre? Australia's national union education program', Australian Journal of Adult Learning, vol 49 no 1, pp 102-125.

Crosby, M (2002). 'Union renewal in Australia', Paper presented at the 2002 ACTU Organising Conference, www.actu.asn.au/organising/news

Ellem, B (2009). 'Unions NSW and Your Rights at Work, 2004 - 2007', Paper presented at the $23^{\text {rd }}$ AIRAANZ Conference, Newcastle, NSW, 4-6 February.

Fletcher, B (1998). 'Labor education in the maelstrom of class struggle', in Wood, E M, Meiksins, $P$ and Yates, $M$ (eds), Rising from the Ashes? Labor in the age of global capitalism, New York, Monthly Review Press.

Horton, M with Kohl, J and Kohl, H (1998). The Long Haul: an Autobiography. New York: Teachers College Press.

Illeris, $\mathrm{K}$ (2002). The Three Dimensions of Learning, London: NIACE.

Labor Council of NSW (2003). Annual Report 2003, Retrieved 9 April 2009, from http://council. labor.net.au/annual_reports/2003/2003-The.html

Muir, K (2008). Worth Fighting For: Inside the yourrightstawork campaign, Sydney, UNSW Press.

Newman, $M$ (1993). The Third Contract: Theory and Practice in Trade Union Training. Sydney: Stewart Victor Publishing.

Sawchuk, P (2006). 'Frameworks for synthesis of the field of adult learning theory', in Fenwick, T, Nesbit, T, and Spencer, B (eds), Contexts of Adult Education: Canadian Perspectives. Toronto: Thompson Educational Publishing.

Wheelahan, L (2007). 'How competency-based training locks the working class out of powerful knowledge: a modified Bernsteinian analysis', Britisb Journal of Sociology of Education, vol 28, no 5, pp 637-651.

Wheelahan, L (2008). 'What about knowledge? The deskilling of teachers' work', in The Australian TAFE Teacher, Autumn, pp 6-7. 


\section{COPYRIGHT INFORMATION}

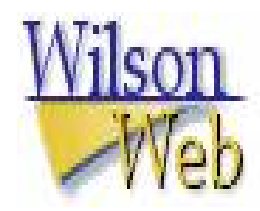

Title: Between immediacy and imagination: the place of the educator and organiser in union renewal

Source: Stud Educ Adults 42 no1 Spr 2010 p. 34-46

ISSN: 0266-0830

Publisher: National Institute of Adult Continuing Education

21 De Montfort Street, Leicester LEI 7GE, England

The magazine publisher is the copyright holder of this article and it is reproduced with permission. Further reproduction of this article in violation of the copyright is prohibited. To contact the publisher: http://www.niace.org.uk/

This article may be used for research, teaching and private study purposes. Any substantial or systematic reproduction, re-distribution, re-selling, loan or sublicensing, systematic supply or distribution in any form to anyone is expressly forbidden. The publisher does not give any warranty express or implied or make any representation that the contents will be complete or accurate or up to date. The accuracy of any instructions, formulae and drug doses should be independently verified with primary sources. The publisher shall not be liable for any loss, actions, claims, proceedings, demand or costs or damages whatsoever or howsoever caused arising directly or indirectly in connection with or arising out of the use of this material. 